\title{
The Dividend Effect on Stock Price-An Empirical Analysis of Malawi Listed Companies
}

\author{
Byson B. Majanga ${ }^{1}$ \\ ${ }^{1}$ Lecturer, Accountancy Department, The University of Malawi-Polytechnic, Malawi \\ Correspondence: Byson B. Majanga, Lecturer, Accountancy Department, The University of Malawi-Polytechnic, \\ Malawi. E-mail: majangabyson2014@gmail.com \\ Received: July 8, 2015 \\ doi:10.5430/afr.v4n3p99 \\ Accepted: August 5, 2015 \\ Online Published: August 10, 2015 \\ URL: http://dx.doi.org/10.5430/afr.v4n3p99
}

\begin{abstract}
The estimation of a firm's stock price has been a subject of debate considering the various factors that cause its increase or decrease. Chief among the outstanding factors touted by most scholars is the amount of dividends declared by the firm to its stockholders. This paper aims at establishing if there exists such a direct relationship between a firm's dividends and its stock price with particular emphasis on the Malawi stock exchange. The study analyses secondary data sets of thirteen local companies listed on the Malawi Stock Exchange for the period 2008 to 2014 inclusive. Using the correlation analysis stock price as an independent variable, and dividends, retention ratio, profit after tax, earnings per share and return on equity, as dependent variables, over the seven years, the study shows a strong positive association between stock price The study therefore establishes that on the Malawi Stock Exchange (MSE), there is a strong positive relationship between a firm's dividends and its stock price on the stock market. The study further finds that stock price is an outcome of a number of factors, dividends being one of them and having a very significant contribution. The findings in this study will help investors, both potential and existing; as well as managers of listed companies, who are the stewards, to understand and appreciate the impact of dividend declaration or absence of it, on the psychology of stockholders which later affects the respective company's stock price on the stock exchange.
\end{abstract}

Keywords: Shareholder wealth, Stock price, Dividends, Earnings retention

\section{Introduction}

The principle of wealth creation in finance is mostly based on the notions of dividend payouts and share (stock) price increases. A number of scholars who believe in wealth creation, such as, Bainbridge (1993); Jensen (2001); Brigham \& Ehrhardt (2002); Brealey \& Myers (2003), and Moyer, McGuigan \& Kretlow (2003) argue that shareholder wealth is maximised when the company gives out a regular dividend to shareholders and when the stock price appreciates on the stock market so that the investor makes some capital gains. It is assumed that stock holder wealth creation is the priority objective of most listed companies (Watson \& Head, 1998), and therefore existing and potential shareholders focus much on how their investment in a listed company will be safeguarded and multiplied to their economic benefit.

Unlike the public sector, almost all the private investors are focused on the profit motive which aims at having their investments grown to higher levels. For a company listed on the stock exchange, a number of factors exist which affect the creation of shareholder wealth in as far as the dividend share price matrix is concerned. Regarding stock price, most researchers in their various studies suggest that the share price is mostly affected by the variables of dividend yield, retention ratio, profit after tax, earnings per share, and return on equity. Amongst the outlined variables, it is shown through a number of studies that dividend policy, (which determines how much of the profit to pay out as dividends, and how much to retain), has a significant influence on the stock price of an entity as it trades on the stock market.

The study will investigate the existence of a relationship between a company's dividends and the market performance of its stock on the Malawi Stock Exchange market. To accomplish this objective, the paper is divided into sections. The next section of the paper reviews the literature so far published on areas related to the one under review, followed by the one describes the testable the data and the methodology used. The last section presents the results and the analysis of the findings, and finally, there is a summary and conclusion section. 


\section{Literature review}

The traditional economic theory of demand and supply plays a big role in the pricing of stocks. It is expected, that when demand for a commodity is high, company stocks being one of them, its price will increase, and conversely, when demand is low, the commodity's price decreases. A firm's stocks may be highly demanded by the existing or potential stockholders due to the stockholders' future expectation from holding the stock. As investors always look out for return on their investments, it is argued that most stockholders are interested most in the dividends they get from the firm's profits (Barfield 1995).

The study conducted by Sharif, Purohit, \& Pillai (2015) on factors affecting the stock price revealed that the share price in the Bahrain market is significantly determined by variables of return on equity, book value per share, dividend per share, dividend yield, price earnings, and firm size. Much as their findings identified a number of factors, dividends given to stockholders were key among them. From their study, it was evident that dividends could not be ruled out in establishing the determinants of stock prices on the Bahrain market as corroborated by the findings of Masum (2014), whose study indicates that a dividend policy a company chooses has a significant positive effect on stock prices.

Bitok, et al, (2011) concluded in another study that daily price movements in the NSE are significantly related to investor sentiment and that investors' psychology is a potential explanation for stock price movements. This indicates that the reaction of stockholders plays a vital role in influencing the stock price. The stockholder therefore is considered to be the greatest influence on stock price through their reaction to dividend announcements and expectations. Still linking dividends to the stock price, Aamir \& Zullfiqar (2011) conducted an event study where they studied twenty six dividends announcements for the firms which belonged to cement and oil and gas sector of Pakistan. The study which covered data span of 2004-2008 analysed the impact of dividend announcement on stock prices and it was found that dividend announcement depicts positive impact on share prices of the companies at the time of announcement as well as immediately after such announcements. This means that announcement of a dividend raises high expectations to investors to the extent that some more stocks are sought to be bought with the aim of earning more dividends when payment time comes, hence the increase in stock price following the demand and supply theory.

A similar study relating dividend announcements to stock price was conducted by Andres, et al (2011) using data from Germany, where they found significant share price reactions after dividend announcements, and furthermore, not only did the dividend announcements excite investors but also announcement of an increased dividend. Douglas \& Frank (2013) conducted a study testing the effect of announcing an increased dividend on the stock price's risk adjusted rate of return for a randomly selected sample of 15 firms whose stocks traded on the NYSE or NASDAQ, from the time period November 20, 2008 to July 26, 2012. Applying the appropriate statistical tests for significance the results showed a significant positive market reaction prior to the firms' announcement of increased dividends. In agreement with the investor sentiments principle as depicted by Bitok et al (2011), Douglas \& Frank (2013) concluded that the announcement of the increased dividend is viewed as a signal of good news. Investors appear to receive the increased dividend news as an implicit signal from management that the firm's future cash flows and growth look bright and will culminate into continuously rising stock price. The market's positive reaction to the announcement suggests that management and stockholders have little to fear from initiating increased dividends.

\subsection{The dividend based models}

According to Hashemijoo, Ardekan \& Younes (2012), one of the most important decisions in corporate finance is concerned with the answer of the question on whether the profits of firm be distributed to the shareholders as dividend or it must be reinvested in new opportunities; and if it must be distributed, what proportion of profit must be paid to shareholder and what proportion must be returned to the business. In answering to this question, managers must consider the impact of the dividend policy adopted on maximization of shareholder's wealth and most importantly, the impact on the company's stock price. Attah-Botchwey (2014) conducted a study seeking to find out the impact of dividend payment and its relationship on the share price of some listed companies on the Ghana Stock Exchange (GSE) and how it helps shareholders to make an informed decision on whether to maintain or withdraw their investment and reinvest in other companies. It was found out that as the dividend of companies increase, the share price also rises due to the pressure on the share. The findings suggest that firms with higher dividend payment have their share price going up as well, as a result of higher demand on shares, and firms with lower dividend have their share price going down, all else being equal. A number of models were developed to estimate the stock price of a listed firm at any given period of time. Although the earnings model establish a direct relationship between Earnings Per Share (EPS) and stock prices (Seetharaman \& Raj, 2011), the dividend models are considered the most popular and 
relevant models that explain the stock prices as evidenced by the findings of Foerster \& Sapp (2005), who in their study found that over their entire sample period, dividend based models performed wellint explaining actual prices, and that they performed better than commonly used earnings based models. One of the dividend based model is the Gordon Growth model which proposes that the value of stock reflects the value of the future dividend payments accruing to that share. The model says the discounted future dividends payments from a share reflect its price. Algebraically, the model is shown by this equation:

$$
P_{0}=\frac{D}{1+r}+\frac{D(1+g)}{(1+r)^{2}}+\frac{\left(D(1+g)^{2}\right)}{(1+r)^{3}}+\ldots \ldots \ldots \cdot \frac{D(1+g)^{\mathrm{n}-1}}{(1+r)^{\mathrm{n}}}
$$

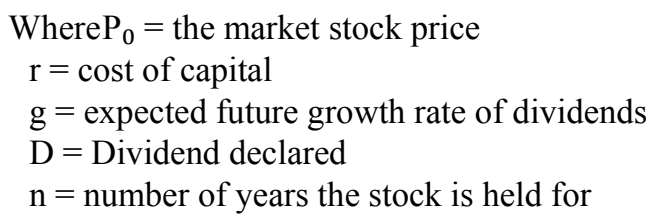

The above model implies that if dividends increase annually at a given constant rate, the stock price will increase given a constant cost of capital (Watson \& Head, 1998). The model shows a direct relationship between dividend and stock prices in that when the dividend grows (the numerator increases), the outcome, the stock price, increases as well. Another study in support of the dividend model was conducted by Khan (2012) in which a sample of twenty five chemical and pharmaceutical companies from Pakistan listed at KSE-100 Index was taken from the period of 2001 to 2010 to explain the relationship between dividends and stock prices after controlling the variables like Earnings per Share, Retention Ratio and Return on Equity. The results of the study indicated that Cash Dividend, Retention Ratio and Return on Equity have significant positive relation with stock market prices and significantly explains the variations in the stock prices.

Contrary schools of thought suggest that low dividends payout (that is, high retention ratios) lead to increased future earnings which in turn translate into increased stockholder's wealth. The proponents of this school of thought argue that the growth in future dividends or shareholder wealth is a product of retained earnings and the cost of capital for the firm (Firer, 1994). However, a study conducted by Arnott \& Asness (2003) found the evidence which contradicts the views of many who believe that substantial reinvestment of retained earnings will fuel faster future earnings growth. They argued that the retention of more earnings is consistent with anecdotal tales about managers solely engaging at times, in inefficient empire building, which in the long run work against maximisation of shareholder's wealth (Watson \& Head, 1998). The dividend model relating the dividend to the stock price goes further to apply even in the banking sector. Joshi (2012) conducted a study on both banking and non banking sector in Nepal. In his study, secondary data was used to examine the impact of dividends on stock prices, and a multivariate linear regression analysis was implied in which current market stock price was taken as a dependent variable and four other variables namely Dividend Per Share (DPS), Retained Earnings Per Share (REPS), Lagged Price Earnings Ratio (P/E ratio) and Lagged Market Price Per Share (MPS) as the explanatory variables. The conclusion drawn in this study revealed that, the impact of dividends on the stock price is more pronounced than that of retained earnings.

\subsection{The Malawi Stock exchange (MSE)}

The Malawi Stock Exchange is one of the youngest stock markets on the globe and was inaugurated in March 1995 and opened for business for the first time on 11 November 1996, under the supervision and sponsorship of the Reserve Bank of Malawi. The first company to be listed then was Malawi's largest insurance firm, the National Insurance Company (NICO). (http://www.mse.co.mw/profile.php) The main function of the Malawi Stock Exchange was to serve a critical need in the Malawi economy of offering an alternative avenue of raising capital for companies to grow; and provide a link between capital raisers and investors seeking profitable investments. The Stock Exchange was also established as a vessel through which Government would successfully privatize companies into the hands of many local Malawians investors. Unlike in other developed economies, where there exists more than one stock market, MSE is the only stock market in Malawi which by end of 2014 had 13 local companies and one foreign company on its list.

\section{Methodology}

The purpose of this study is to contribute towards the important subject in financial management which aims to ascertain the factors significantly influencing stock prices in an efficient stock market with reference to listed companies on the Malawi Stock Market. The study was conducted through secondary research via a detailed analysis of companies' annual reports, and the Malawi Stock Exchange (MSE) annual market performance reports. The data 
was gathered for seven consecutive years from 2008 to 2014 inclusive. From the history of the Malawi Stock market, no new company had ever been registered since 2008 to 2014 and therefore the selection of the study period is not constrained in this respect.

\subsection{Variables}

In this study, market stock price (SP) is taken as dependent variable which is dependent on the behaviour of five other independent variables namely dividend per share (DPS), retention ratio (RR), earnings per share (EPS), return on equity (ROE), and net profit after tax (PAT). Dividend per share (DPS) signifies how much dividends paid by a company are allocated to each share held by stock holders. Researchers such as Nishat \& Irfan (2003) found positive relation between dividend and stock price. The retention ratio (RR) is calculated by subtracting total dividend from total earnings and then dividing the resultant amount by total earnings. Earnings per share (EPS) represent the amount of earnings attributable to each outstanding share of a company's stock, and return on Equity (ROE) is calculated by dividing profit after tax with shareholders equity

The annual reports of the thirteen local companies listed on the Malawi Stock Exchange were analysed to identify the retention ratio, profit after tax, earnings per share, return on equity as well as annual dividends announced by each company at the end of each company's financial year. Eleven of these companies have their financial year ending on 31 December, one company with year ending on 31 March and another with 30 September. The author considers this misalignment of year end dates as having an immaterial effect on the findings

The data sets for each company were subject to a correlation test to establish a linear relationship between them and determine the strength of such relationship if any. According to Taylor (1990), correlation analysis is one of the most widely used and reported statistical methods in summarizing medical and scientific research data. It is often useful to determine if a relationship exists between two different variables and how significant or how strong is this association between the two variables. The correlation coefficient or the $r$ coefficient is a statistic used to measure the degree or strength of this type of relationship.

According to Malgady \& Krebs (1986) and Fenton \& Neil (2012), the correlation coefficient is a number between -1 and 1 that determines whether two paired sets of data (in this case, each of the independent variables in turn, and stock price) are related. The closer to 1 , the more the evidence of a positive linear correlation and the closer to -1 , the more the evidence of a negative linear correlation and that when the correlation coefficient is close to zero there is no evidence of any relationship. A positive correlation means that the scores tend to vary directly, that is, as one score increases, the other score increases, and, as one score decreases, the other score decreases. A negative correlation indicates an inverse relationship, that is, as one score increases, the other decreases.

The independent variables $(\mathrm{X})$ being the annual dividend, the retention ratio, profit after tax, earnings per share, and return on equity in turns; and the dependent variable (Y) being stock price at the end of the calendar year, the correlation coefficient for each company was determined through Excel using the formula below:

$$
r=\frac{n \sum X Y-\sum X \sum Y}{\sqrt{\left\{n \sum X^{2}-\left(\sum X\right)^{2}\right\}\left\{n \sum Y^{2}-\left(\sum Y\right)^{2}\right\}}}
$$

Where $\quad r \quad=$ correlation coefficient,

$\mathrm{n} \quad=$ number of observations, that is, 91 observations

$\mathrm{X} \quad=$ independent variable (s)

$\mathrm{Y}=$ dependent variable, that is the stock price by 31 December

\section{Analysis and discussion of results}

The results of the effect of dividends on stock price are presented in the following section. First to be presented is the descriptive analysis followed by the Pearson's correlation analysis to ascertain the relationship between stock price and all other independent variables, with a particular emphasis on dividends.

\subsection{Descriptive statistics}

Table 1 below shows the detail of descriptive statistics of variables that affect the market price of companies listed on the Malawi Stock Exchange (MSE) for the period 2008 to 2014. Market stock price which is the dependent variable in the model ranges from 100 to 45310 with a mean value of 6074.82 and standard deviation is 9942.46 . The first explanatory variable is dividend per share with a mean value of 258.055 and a standard deviation of 406.835 , 
followed by the retention ratio which ranges from 0 to 0.851 and its mean value and standard deviation is 0.3754 and 0.21121 respectively. Profit after tax, which is the third explanatory variable, has a minimum value 0.23 billion and maximum value 16.17 billion with mean 5218.94 and standard deviation of 8391.62 . The fourth explanatory variable is earnings per share with a mean value of 17.006 and a standard deviation of 86.8819 . Finally, the fifth explanatory variable, return on Equity shows the minimum value 0.10289 and maximum value 1.3921 with mean 0.20376 and standard deviation 0.11134 .

Table 1. Descriptive Statistics

\begin{tabular}{lllllllll}
\hline & & & & & \multicolumn{3}{c}{ Skewness } & \multicolumn{3}{c}{ Kurtosis } \\
\cline { 7 - 9 } & Mini & Maxi & Mean & Std dev & Statistic & Std error & Statistic & Std error \\
\hline SP & 100 & 45310 & 6074.82 & 9942.46 & 2.25467 & 0.19946 & 4.92945 & 0.38631 \\
DPS & 0 & 1850 & 258.055 & 406.835 & 2.03708 & 0.19781 & 3.80863 & 0.38554 \\
RR & 0 & 0.851 & 0.3754 & 0.24121 & -0.1139 & 0.18527 & 3.11721 & 0.36903 \\
PAT & 23.7711 & 16178.3 & 5218.94 & 8391.62 & -1.7291 & 0.18527 & 12.5527 & 0.36903 \\
EPS & 33.2304 & 423.97 & 17.006 & 86.8819 & 2.9121 & 0.18527 & 47.2193 & 0.36903 \\
ROE & 0.10289 & 1.3921 & 0.20376 & 0.11134 & 1.99743 & 0.18527 & 19.0042 & 0.36903 \\
\hline
\end{tabular}

4.2 Correlation analysis

A correlation matrix of all variables included in the analysis is presented in table 2 below, which is calculated based on data of 91 observations. The table shows that stock price is negatively associated with profit after tax and retention ratio, and is positively associated with return on equity, earning per share and strongly with dividend per share.

Table 2. Pearson Correlation Coefficient between variables of 13 MSE listed companies (91 observations)

\begin{tabular}{lllllll}
\hline & SP & DPS & RR & PAT & EPS & ROE \\
\hline SP & 1 & & & & & \\
DPS & 0.799 & 1 & & & & \\
RR & -0.293 & -0.522 & 1 & & & \\
PAT & -0.19 & 0.118 & 0.306 & 1 & & \\
EPS & 0.433 & 0.433 & -0.176 & 0.042 & 1 & \\
ROE & 0.221 & 0.229 & 0.004 & -0.114 & -0.423 & 1
\end{tabular}

An overall observation and analysis of all the observed variables (91 in total) revealed and cemented the findings of researchers such as Yilmaz \& Gulay (2006) and Khan, Amir, Qayyum, Nasir, \& Khan (2011), whose studies show the existence of a strong direct relationship between stock price and dividends.

\section{Limitations of the study}

The outcome of this study could still be subject to further debate and scrutiny due to a number of inconsistencies in the data from the annual reports which include the fact that not all companies have similar financial year ends, that is, 31 December; the companies operate in different industries and therefore do not share similar characteristics and they are viewed differently by stockholders; the companies were not listed on the stock exchange on similar dates and therefore the stock price could also be affected by this fact. Another important limitation is that highlighted by Asamoah (2014) who found that despite the challenges associated with using correlation, it still remains useful but only in bi-variate data analysis methods used for predictions; in more complex correlation statistics, relationship between two variables can be established only when the influence of other variables is removed or factored out. As already highlighted, stock price is determined by a number of factors, dividends being one of them and therefore the influence of the other factors cannot be ignored or be deemed insignificant. The author acknowledges the influence of these other factors on stock prices.

\section{Conclusion}

The above mentioned limitations notwithstanding, the findings of this study reveal that there is a significant positive relationship between dividends and stock price as touted by the dividend valuation models of determining stock 
prices. The author, however, is of the view that stock price is determined by some other factors beyond the control of the company's management but these factors are not as strong as dividends. The findings support the previous findings by other scholars much as the emphasis of this study was restricted to companies listed on the Malawi Stock Exchange.

For a company therefore to improve its rating on the stock market, which is informational efficient, it must consider increasing the wealth of its shareholders by increasing dividends payment overtime which later coaxes more shareholders to buy the stock hence piling up pressure on the price of the stock, leading to the price increase.

\section{References}

Aamir, M., \& Zullfiqar, S. (2011). Dividend announcements and the abnormal stock returns for the event Firm and its rivals, Australian Journal of Business and Management Research Vol.1 No.8 pp72-76.

Andres, C., Betzer, A., Bongard, I., Haesner, C., \& Theissen, E. (2011). Dividend Announcements Reconsidered: Dividend Changes versus Dividend Surprises. http://dx.doi.org/10.2139/ssrn.1763201

Arnott, R., \& Asness, C. (2003). Surprise! Higher Dividends= Higher Earnings Growth. Financial Analyst Journal. CFA Institute. http://dx.doi.org/10.2469/faj.v59.n1.2504

Asamoah, M. K. (2014). Re-examination of the limitations associated with correlational research. Journal of Educational Research and Reviews Vol. 2(4), pp. 45-52, July 2014

Attah-Botchwey, E. (2014). The Impact of Dividend Payment on Share Price of Some Selected Listed Companies on the Ghana Stock Exchange. International Journal of Humanities and Social Science Vol. 4, No. 9(1); July 2014.

Bainbridge, S. M. (1993). In Defence of Shareholder Wealth Maximisation: A Reply to Professor Green. Washington and Lee Law Review. Vol 50, Issue 4 Article 5

Barfield, R. (1995). Shareholder value in practice. The Treasurer magazine, January 1995.

Bitok, J., Kiplangat, A., Tenai, J., \& Rono., L. (2011). Determinants of investor confidence for firms listed at the Nairobi stock exchange, Kenya. Annual Conference on Innovations in Business \& Management, London, UK.

Brealey, R.A. \& Myers, S.C. (2003). Principles of Corporate Finance, $7^{\text {th }}$ Edition, McGraw- Hill/Irwin, pp. 22-23.

Brigham, E. F., \& Ehrhardt, M.C. (2002). Financial Management: Theory and Practice, $10^{\text {th }}$ Edition, Harcourt College Publishers, pp. 10-11.

Douglas, L., \& Frank, B. (2013). The impact of increased dividend Announcements on stock price: A test of market efficiency. Proceedings of ASBBS, Volume 20 Number 1

Fenton, N., \& Neil, M. (2012). Risk Assessment and Decision Analysis with Bayesian Networks, CRC Press.

Firer, C. (1994). The P/E ratio and the cost of Equity Capital. Investments Analysts Journal No 38-Summer 1993/94

Foerster, S., \& Sapp, S. (2005). The Dividend Discount Model in the Long-Run: A Clinical Study, Journal Of Applied Finance.

Hashemijoo, M., Ardekan, A., \& Younes, N. (2012). The Impact of Dividend Policy on Share Price Volatility in the Malaysian Stock Market. Journal of Business Studies Quarterly. 2012, Vol. 4, No. 1, pp. 111-129. ISSN 2152-1034

Jensen, M. C. (2001). Value Maximization, Stakeholder theory, and the Corporate Objective Function, Amos Tuck School of Business, Dartmouth College Working paper No. 01-09.

Joshi, R. (2012). Effects of Dividends on Stock Prices in Nepal, NRB Economic Review.

Khan, K. (2012). Effect of Dividends on Stock Prices- A Case of Chemical and Pharmaceutical Industry of Pakistan, Proceedings of 2nd International Conference on Business Management (ISBN: 978-969-9368-06-6)

Khan, K. I., Amir, M., Qayyum, A., Nasir, A., \& Khan, M.I. (2011). Can dividend decisions affect the stock prices: A case of dividend paying companies of KSE. International Research Journal of Finance and Economics, Volume 76(2011), pp. 67-74.

Malawi Stock Exchange Web Page: http://www.mse.co.mw/profile.php

Malgady, R.G., \& Krebs, D.E. (1986). Understanding Correlation Coefficients and Reggression. Journal of the American Physical Therapy Asociation, 66:110-120 
Masum, A. (2014). Dividend Policy and its Impact on Stock Price - A Study on Commercial Banks Listed in Dhaka Stock Exchange. Global Disclosure of Economics and Business, Volume 3, No 1 (2014).

Moyer, R. C., McGuigan, J.R., \& Kretlow W.C. (2003). Contemporary Financial Management, $9^{\text {th }}$ Edition, Thomson Southwestern, pp. 7-9.

Nishat, M., \& Irfan, C. M. (2003). Dividend Policy and Stock Price Volatility in Pakistan. $11^{\text {th }}$ Pacific Basin Finance, Economics and Accounting Conference.

Seetharaman, A., \& Raj, J.R. (2011). An Emperical study on the impact of Earnings Per Share on Stock prices of a listed bank in Malaysia. International Journal of Applied Economics and Finance. 5(2) ISSN 1991-0886/ DOI 10.3923/ijaef/.2011.114.126.

Sharif, T., Purohit, H., \& Pillai, R. (2015). Analysis of Factors Affecting Share Prices: The Case of Bahrain Stock Exchange, International Journal of Economics and Finance; Vol. 7, No. 3.

Taylor, R. (1990). Interpretation of the Correlation Coefficient: A Basic Review. Journal of Diagnostic Medical Sonography, Vol 6. Issue 1: 35-39. http://dx.doi.org/10.1177/875647939000600106

Watson, D., \& Head, T. (1998). Corporate Finance: Principles \& Practice. London, Financial Times. ISBN 0 273630083.

Yilmaz, AK \&Gulay, G (2006). Dividend policies and price-volume reactions to cash dividends on the stock market: evidence from the Istanbul Stock Exchange, Emerging Markets Finance and Trade, vol. 42, no. 4, pp. 19-49. http://dx.doi.org/10.2753/REE1540-496X420402 